\title{
e norden
}

\section{Gróska - lífskraftur}

Formennskuáætlun Íslendinga

í Norrænu rádherranefndinni 2014 


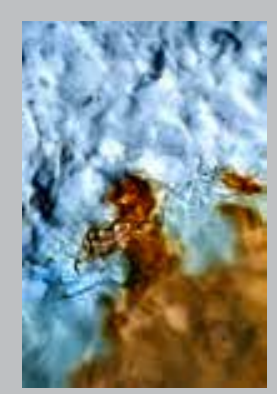

Gróska - lífskraftur

Formennskuáætlun Íslendinga i Norrænu rádherranefndinni 2014

ISBN 978-92-893-2620-9

http://dx.doi.org/10.6027/ANP2013-768

ANP 2013:768

(C) Norræna rádherranefndin 2013

Umbrot: Jette Koefoed

Ljósmyndir

Kápa: Einar Ólason

bls. 6, 12, 15, 18, 20: Image Select

bls. 16: Bee-Line

bls. 27: Sebastien Dehesdin

Upplag: 700

Leturgerð: Meta LF

Pappír: Munken Polar

Prentun: 07 Media a.s

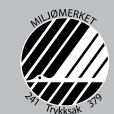

Printed in Norway

\section{Norrænt samstarf}

Norræna samstarfið er eitt umfangsmesta svæðasamstarf í heiminum. Samstarfið nær til Danmerkur, Finnlands, Íslands, Noregs og Svípjódar auk Álandseyja, Færeyja og Grænlands.

Norræna samstarfið er pólitískt, efnahagslegt og menningarlegt og skiptir miklu i evrópsku og alpjódlegu samstarfi. Í norrænu samstarfi er unnið að bví að styrkja stöðu Norðurlanda í sterkri Evrópu.

Með norrænu samstarfi er unnið að bví að efla norræna og svæðisbundna hagsmuni i albjódlegu umhverfi. Sameiginleg gildi landanna styrkja stöðu Norðurlanda og skipa peim meðal beirra svæдa í heiminum par sem nýsköpun og samkeppnishæfni er mest.

\section{Norræna rádherranefndin}

Ved Stranden 18

DK-1061 København K

Sími (+45) 33960200

www.norden.org 


\title{
Onorden
}

\author{
Gróska - lífskraftur \\ Formennskuáætlun Íslendinga \\ í Norrænu rádherranefndinni 2014
}

\section{Efnisyfirlit}

4 Formáli

7 Gróska - lífskraftur

13 Norræn náttúruvitund

19 Tækifæri til sóknar

23 Pekking á nýjum tímum

26 Skapandi Norðurlönd

32 Velferð og pátttaka 


\section{Formáli}

Gróska og lífskraftur er yfirskrift formennskuáætlunar Îslendinga í Norrænu rádherranefndinni árið 2014.

Pessi hugtök eru grunngildin í premur formennskuverkefnum Íslands.

Í Norræna lífhagkerfinu er leitað leiða til að nýta betur lifandi auðlindir okkar hvort sem pær er að finna í lofti, á ládi eda í legi. Lífmassinn er vannýtt auðlind sem lífhagkerfi framtídarinnar munu byggja afkomu sína á. Í dag fer gríðarlega mikið af lífrænum verðmætum í súginn á sorphaugum úti um víða veröld með tilheyrandi álagi á umhverfið. Matvælastofnun Sameinuðu pjódanna áætlar að priðjungur matvælaframleiðslu heimsins endi sem úrgangur en á sama tíma svelta milljónir manna heilu hungri. Pessu verðum við að breyta. Á Norðurlöndum er að finna mikið hugvit og skapandi hugsun sem er forsenda pess à ryðja lífhagkerfinu braut og ná forskoti á pví sviði.

Prátt fyrir niðursveiflu sídustu ára eru innviðir norrænna samfélaga sterkir. Undirstöðuaudlindir okkar eru enn á sínum stað; skógarnir, málmarnir, fiskurinn og orkan. Frumkrafturinn kemur pó frá fólkinu sem byggir Norðurlönd og skapar verðmæti og velferð með hugviti sínu og hæfileikum. Menntunarstig er hátt og félagslegt öryggi mikid. En almenn velferd̀ af pví tagi sem ríkir á Norðurlöndum er ekki sjálfsagður hlutur og mikilvægt er að skipa málum pannig að hún verði sjálfbær pegar til lengri tíma er litið. Efnahagssveiflur setja velferðarkerfið í augljósa hættu. Með formennskuverkefninu Norræna velferðarvaktin vilja Íslendingar varpa ljósi á viðnámsprótt norræna velferðarríkisins og hæfileika pess til að grípa hratt inn í og mæta áföllum pegar kreppir snögglega að.

Skapandi greinar skipta verulegu máli í atvinnu- og efnahagslífi Norðurlanda. Sköpunarkraftur og hugmyndaauðgi pess fólks sem starfar við margvíslegar greinar á pessu sviði er einstök auðlind á Norðurlöndum. Mikilvægt er að skapa pannig umgjörd að pær nái að blómstra - listræna og samfélagslega gildið er augljóst og efnahagslegi ávinningurinn er ótvíræður. Með verkefninu Norræni spilunarlistinn vilja Íslendingar styðja við kynningu og útflutning á norrænni tónlist. Ekki er ástæða til annars en 
að ætla að verkefnið haldi áfram af eigin rammleik pegar stuðningi við pað lýkur.

Samstarf Norðurlanda hvílir á traustum grunni, lýəræðið er virkt og félagsleg auðlegð er mikil. Lifandi pjóðfélagsumræða og öflug samkennd er til vitnis um ríka og fjölbreytta menningararfleifð sem pjóðirnar eiga sameiginlega. Norðurlönd hafa áhrif á alpjódavettvangi og samanlagður efnahagur okkar er sterkur. Við búum yfir grósku og lífskrafti sem okkur ber ad nýta til fullnustu.

Íslendingar setja norrænt samstarf í öndvegi og taka ad sér formennsku í Norrænu ráðherranefndinni með stolti og eftirvæntingu.
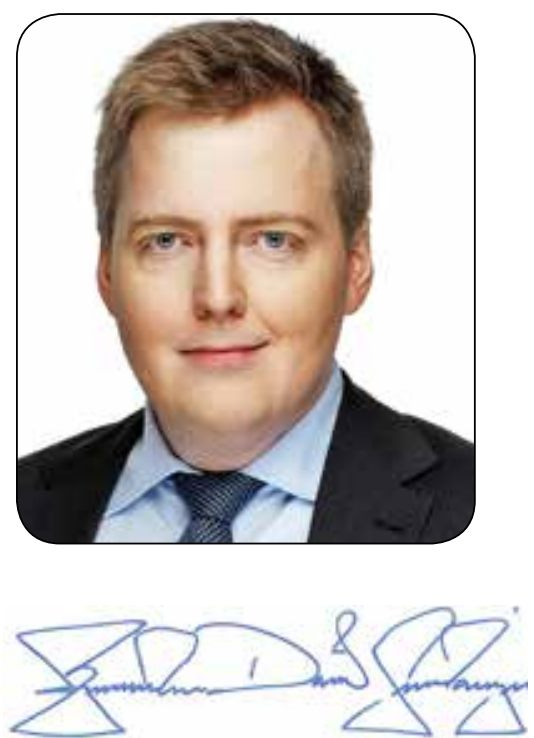

Sigmundur Davíd Gunnlaugsson forsætisrádherra
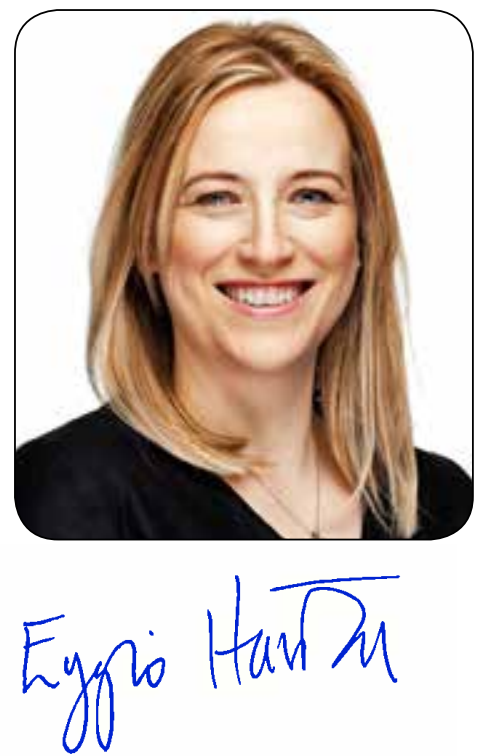

Eygló Harðardóttir samstarfsráðherra Norðurlanda 


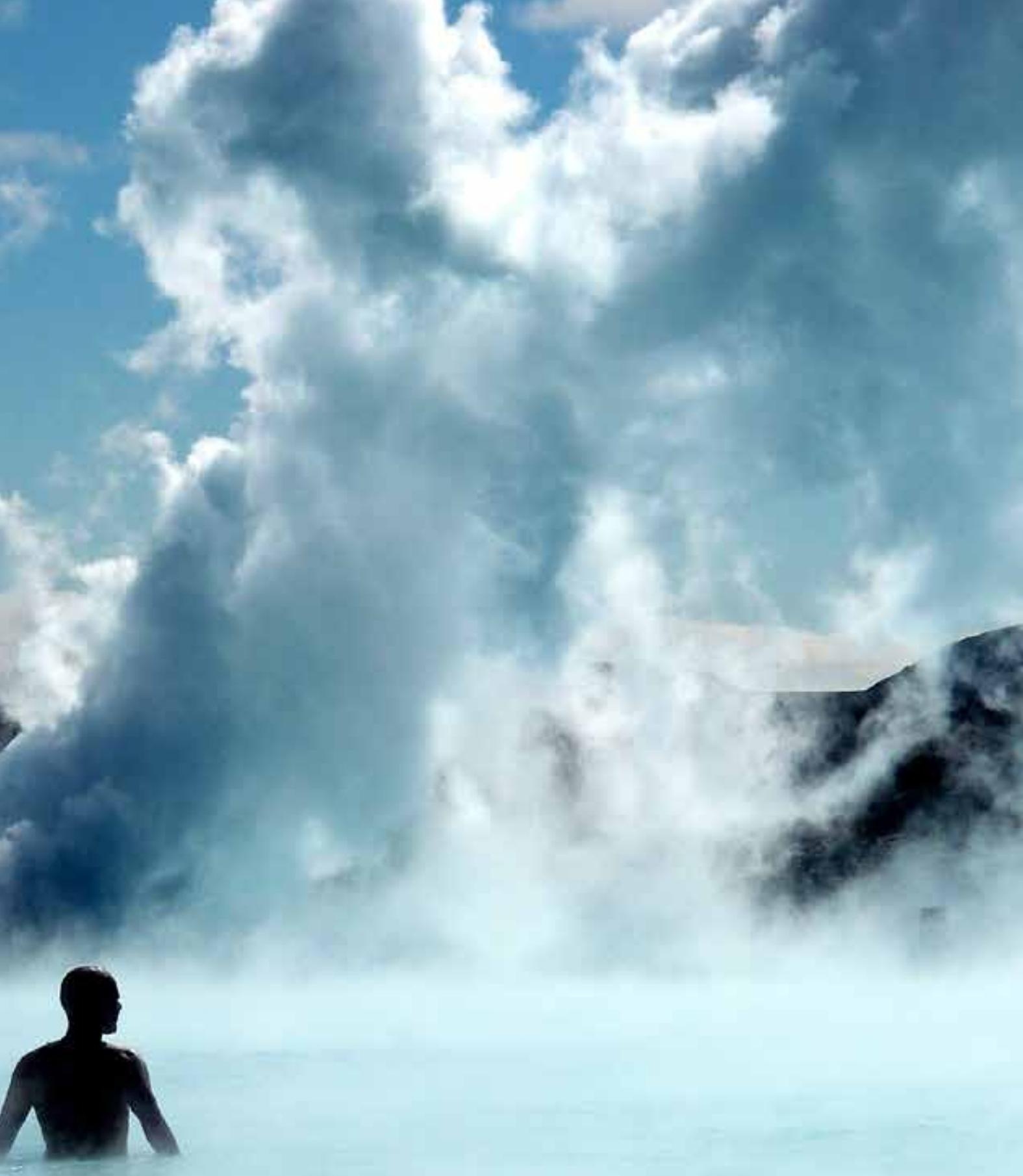




\section{Gróska - lífskraftur}

Ímynd Norðurlanda er samsett úr nokkrum páttum sem eru að̃ mörgu leyti einkennandi fyrir pær pjóðir sem byggja svæðið og veita peim sérstöðu á margan hátt. Norðurlönd vilja halda í pá sérstöðu enda má líkja ímyndinni við verðmætt vörumerki.

Pað er vel pekkt að Norðurlönd skipa sér í fremstu röð pegar pjóðir heims eru bornar saman samkvæmt viðurkenndum alpjódlegum mælistikum. Prátt fyrir að ytri skilyrði hafi versnað í efnahagsprengingum sídustu ára halda Norðurlönd enn ímynd sinni um jöfnuð, frið, velferð og hagsæld. Sérstaða Norðurlanda felst enn fremur í pví að hér myndaðist snemma gagnkvæmur skilningur á pví ad leysa beri ágreining og milliríkjadeilur eftir diplómatískum leiðum, á vettvangi Sameinuðu pjódanna og annarra alpjódlegra stofnana.

Norðurlönd urðu snemma ötulir málsvarar sjálfbærrar próunar, hugmyndafræði sem nú er útbreidd um allan heim. Jafnrétti er sömuleiðis stór páttur i i imynd Norðurlanda og er forgangsmál i samstarfi Norðurlanda við aðrar pjódir. Enda pótt um sé að ræða lönd sem eru á margan hátt ólík og móta sér mismunandi afstödu til mála, eftir hagsmunum hverju sinni, deila pau ákveðnum grunngildum sem gera peim kleift að tala einni röddu.

Svæðasamstarf Norðurlanda er eitt pað elsta sinnar tegundar í heiminum. Samstarfið er um leið samnefnari peirra gilda sem Norðurlönd standa fyrir. Norræna notagildið hefur frá upphafi verið leiðarljós samstarfsins en samstaðan og samvinnan sem af pví leiðir eru jafnmikilvæg pannig er norrænt samstarf markmið í sjálfu sér. Á tímabilum hefur verið sótt að norrænu samstarfi og margir efast um framtí̉ pess. Pað hefur með sveigjanleika og aðlögunarhæfni nád að standa af sér ágjöf efasemdarmanna og sjaldan verið öflugra og staðið styrkara en nú. Ísland vill nýta formennskuárið til pess að beina samstarfinu inn á nýjar og spennandi brautir par sem hægt er að auka norræna notagildið frekar. Formennskuverkefnin Norræna lífhagkerfið, Norræna velferðarvaktin og Norræni spilunarlistinn verða í brennidepli á formennskuári Íslands. 


\section{Græn samfélagspróun}

Íslendingar vilja beina kastljósinu að lífrænum auðlindum Norðurlanda sem nýta má mun betur en gert er í dag. Áherslur á grænan hagvöxt og sjálfbæra próun haldast í hendur í verkefninu um próun Norræna lifhagkerfisins. Auðlindir geta gengið til purrðar og pví ber okkur skylda til að tryggja sjálfbæra nýtingu peirra og koma í veg fyrir sóun. Til að tryggja grænan hagvöxt og sjálfbæra próun til frambúdar er mikilvægt að tengja pessar áherslur við uppeldi og menntun. Áhersla verður lögð á að sameina pessi svið með verkefnum par sem sköpun verður notuð sem kennslu- og rannsóknaraðferd.

Lífhagkerfið er notad um pá starfsemi sem byggist upp í kringum hámarksnýtingu lífrænna audlinda úr sjó og af landi. I sjálfbærri nýtingu pessara auðlinda felast mikilvæg tækifæri til að auka velferð og örva grænan hagvöxt á Norðurlöndum, til dæmis með framleiðslu lífmassa og skilvirkari notkun hans á ýmsum sviðum samfélagsins.

Norræna liffhagkerfið er umfangsmikið og pverlægt verkefni par sem rádherranefndirnar um umhverfismál (MR-M), fiskveiðar, fiskeldi, landbúnad, matvæli og skógrækt (MR-FJLS), atvinnu-, orku- og byggdamál (MR-NER), menntun og rannsóknir (MR-U) og menningu (MR-K) leiða saman krafta sína auk fjölmargra norrænna stofnana, fræðimanna og annarra hagsmunaadila í löndunum. Undir formerkjum Norræna lífhagkerfisins verður unnið að ýmsum verkefnum sem öll miða að frekari virðisauka fyrir umhverfi og samfélag. Norðurlönd hafa gódar forsendur til að ryðja brautina fyrir lífhagkerfið og pví er mikilvægt að pau séu leiðandi á pví sviði.

\section{Ný viðfangsefni fyrir norræna velferð}

Norrænu velferðarkerfin standa stöðugt frammi fyrir nýjum áskorunum. Breytt aldurssamsetning íbúa er nærtækt dæmi. Krafan um sjálfbær velferðarkerfi kallar á endurmat á ríkjandi áherslum. Aukið atvinnuleysi og alpjóðlegar efnahagskreppur leiða af sér ný viðfangsefni sem krefjast úrlausna. Skemmst er að minnast efnahagshrunsins sem varða áslandi sídla árs 2008. Íslenskt velferðarkerfi stód pá frammi fyrir mikilli ógn - á skömmum tíma purfti að takast á við samfélagsleg vandamál af stærðargrádu sem fáir gátu séd fyrir. Reikna má med ad alpjódlegar efnahagskreppur hafi áhrif alls staðar á Norðurlöndum og að enn muni reyna á polrif norrænu velferðarkerfanna á næstu árum. 
Velferðarkerfið hefur lengi verið viðfangsefni í norrænu samstarfi. Norrænu forsætisrádherrarnir hleyptu verkefninu Sjálfbær norræn velferð af stokkunum í ágúst 2013. Meginmarkmið pess er að próa nýjar lausnir í velferðarmálum á Norðurlöndum. Pað felur meðal annars í sér gerð svokallaðrar Könberg-skýrslu sem unnin er að frumkvæði norrænu heilbrigðisrádherranna. Á formennskuárinu taka Íslendingar við verkefninu Sjálfbær norræn velferd af Svíum og munu tryggja gott áframhald pess.

Með formennskuverkefninu Norræna velferðarvaktin munu Íslendingar leggja sitt af mörkum til aukinnar sjálfbærni velferðarkerfisins og tengja pad áherslum verkefnisins Sjálfbær norræn velferð. Norræna velferðarvaktin byggist að hluta til á reynslu Íslendinga af velferðarvakt sem ríkisstjórn Îslands kom á laggirnar snemma árs 2009 til að bregðast við vanda í kjölfar efnahagshrunsins. Verkefnið felur meðal annars í sér rannsóknir á viðbrögðum við afleiðingum alvarlegra efnahagskreppna á Norðurlöndum undanfarna áratugi, hvaða lærdóm megi draga af peim aðgerðum sem gripið var til og hvaða afleiðingar megi leiða líkur að stafi af aðgerðarleysi stjórnvalda. Einnig mun verkefnið próa velferðarvísa til grundvallar stefnumótun og aðgerðum í velferðarmálum á Norðurlöndum.

\section{Norðurlönd án hindrana}

Í norrænu samstarfssamningunum sem marka umgjörd samstarfsins endurspeglast vilji landanna til að gera Norðurlönd að einu svæði par sem samgangur milli fólks er greiður og hægt er að stunda viðskipti yfir landamæri án pess að ósamrýmanlegar reglur girði par fyrir. Stjórnsýsluhindranir hafa áhrif á íbúa, fyrirtæki og frumkvödlastarfsemi á Norðurlöndum og purfa löndin í sameiningu ad vinna að pví að draga úr peim. Pótt mikið hafi verið gert á liðnum árum til að ryðja stjórnsýsluhindrunum úr vegi er enn verk að vinna. Petta viðfangsefni sem vonast var til að yrði tímabundið í norrænu samstarfi er nú komið til að vera. Sterkan pólitískan vilja parf til að ná frekari árangri og koma parf í veg fyrir à nýjar hindranir fylgi i kjölfar lagasetningar í löndunum. Vilji Norðurlönd styrkja samkeppnisstöðu sína í hnattvæddum heimi og skipa sér sess sem svæði par sem ákjósanlegt er að hasla sér völl, setjast að og stunda viðskipti, nám og rannsóknir parf að̀ gera betur.

Mikilvægt er að nýtt skipulag á vinnunni gegn stjórnsýsluhindrunum sem innleiða á í upphafi formennskuársins fái gott brautargengi og verði pað afl sem vonir standa til. Einkum er brýnt að takast á við pær hindranir sem bent var á í skýrslu vinnuhóps um hindranir á sviði félags- og vinnumála sem út 
kom 2012 en par er jafnframt að finna tillögur um leiðir sem vinnuhópurinn telur færar til úrlausna og mikilvægt er að fylgja eftir.

\section{Lifandi menning}

Menningarsamstarfinu hefur ávallt verið gert hátt undir höfði i norrænu samstarfi og hin sídari ár hefur athyglin í vaxandi mæli beinst að skapandi greinum sem eru í mikilli sókn í öllum löndunum. Í skapandi greinum felst mikil auðlind sem virkja parf betur. Með pví að leiða saman pá krafta sem búa í skapandi greinum og kynna fyrir umheiminum pað besta sem Norðurlönd hafa að bjóda næst sá virðisauki sem stefnt er að i norrænu samstarfi. pá ber að hafa í huga að frumkvæðið í grasrótinni er dýrmætt, skapa parf umgjörd sem styður við nýskapandi hugsun og frjóar hugmyndir.

Ísland vill nýta pað tækifæri sem gefst á formennskuárinu til að styðja við gróskumikið starf tónlistarmanna á Norðurlöndum. Norræni spilunarlistinn er próunarverkefni sem hefur pað markmið að efla norrænan tónlistarmarkað og vekja athygli á norrænni tónlist. Verkefnið veitir tækifæri til að auka útflutningsmöguleika norrænnar tónlistar, búa til samtímaheimild um norræna tónlist og að sýna um leið fram á mikilvægi norrænnar samvinnu.

\section{Norrænt notagildi utan Norðurlanda}

Norræna rádherranefndin hóf samstarf við Eystrasaltsríkin í byrjun tíunda áratugarins og markar bað upphaf eiginlegs samstarfs Norðurlanda við grannsvæðin. Samstarfið við Norðvestur-Rússland hófst 1995. Sídan hefur mikið vatn runnið til sjávar - alpjódlegt samstarf Norrænu ráðherranefndarinnar verður æ mikilvægara eftir pví sem bað teygir anga sína vídar. Slíkt samstarf fer fram á vettvangi ESB, til dæmis um Evrópska háskólann í húmanískum fræðum og innan Norðlægu víddarinnar auk annarra svæðisbundinna samtaka, svo sem Eystrasaltsrádsins og Norðurskautsrádsins. Einnig starfa norrænu sendirádin náið saman en rádherranefndin hefur hvatt til og veitt pví samstarfi stuðning. Pá hefur verið litið til samstarfs við Pýskaland og Pólland og nágranna Norðurlanda í vestri, Kanada og Bandaríkin. Allt er petta til marks um að sóst er eftir norrænu samstarfi langt út fyrir landamæri Norðurlanda og ber styrkum stoðum samstarfsins vitni.

Á formennskuári Svía lauk vinnu við endurskoðun reglna um samstarf ráðherranefndarinnar við Eistland, Lettland og Litháen og við Norðvestur- 
Rússland og um pað samstarf sem beinist að Hvíta-Rússlandi og Barentssvæðinu. Reglurnar öðlast gildi við upphaf formennskuárs Íslands. Nýju reglurnar bera pað með sér að pær hafa verið unnar í gódu samstarfi rádherranefndarinnar og nágrannalandanna og að krafan um sameiginlegt notagildi samstarfsins var höfð að leiðarljósi. Mikill gagnkvæmur áhugi er á samstarfinu og skýrt er hvar hagsmunir fara saman. Gengið er út frá

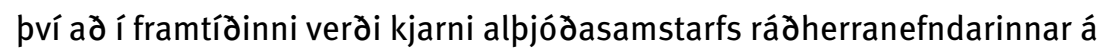
Eystrasaltssvæðinu. Samstarf við önnur lönd og svæði verður skoðað með opnum hug pegar og ef eftir pví verður leitad.

\section{Fjárlög}

Ákveðin efnahagsleg skilyrði hafa gert pað að verkum að nauðsynlegt er að forgangsraða og nýta með skynsamlegum hætti pá fjármuni sem löndin hafa ákveðið að leggja í samstarf Norrænu rádherranefndarinnar. Nú fer fram vinna um endurmat og endurnýjun samstarfsins, tilgangur hennar er að skýra markmið og tryggja árangur norræns samstarfs. 


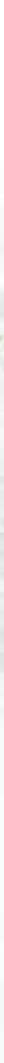




\section{Norræn náttúruvitund}

Norðurlandapjóðir hafa ætíð haft mikinn metnað, verið samstiga og lagt mikið af mörkum á vettvangi umhverfismála jafnt innan sem utan Norðurlanda. Á formennskuárinu munu Íslendingar setja í forgang verkefni sem skapa norrænan virðisauka fyrir umhverfi og samfélag. Slík verkefni eru ekki aðeins pýdingarmikil á norrænum vettvangi heldur einnig sem framlag Norðurlanda til umhverfismála á albjóðlegum vettvangi.

Íslendingar vilja setja græna samfélagspróun í forgang og meðal annars nýta pá möguleika sem felast í uppbyggingu lífhagkerfisins (sjá nánar á bls. 17) til að draga úr loftslagsbreytingum. Með pví að stuðla að umhverfisvænum framleiðsluháttum og sjálfbærri neyslu má draga úr neikvæðum umhverfisáhrifum. Jafnframt er mikilvægt að styrkja vitund fólks um pau verðmæti sem fólgin eru í heilbrigðu umhverfi og náttúru. Lögð verður áhersla á að efla líffræðilega fjölbreytni, pjónustu vistkerfa og umhverfismerkið Svaninn. Einnig verður sjónum beint að betri nýtingu hráefna og úrgangs, málefnum hafsins og samspili loftslags- og orkumála. Auk hinna sérstöku áhersluatriða munu Íslendingar leggja sitt af mörkum til að vel takist til með að innleiða Norræna framkvæmdaáætlun i umhverfismálum 2013-2018 og sameiginlega stefnu Norðurlanda um sjálfbæra próun Gott líf á sjálfbærum Norðurlöndum - Norræn áætlun um sjálfbæra próun.

Íslendingar leggja áherslu á að fyrirbyggja hnignun vistkerfa og styrkja viðnámsprótt peirra. Jafnframt er mikilvægt að byggja upp og endurheimta

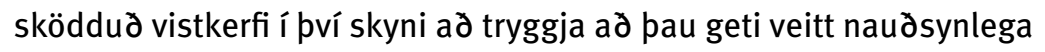
pjónustu til frambúdar. Lýðheilsa og samfélag eru hád pjónustu vistkerfa, pví ber út frá heilsuverndarsjónarmiðum að tryggja pjónustu peirra og vernda græn svæði. Undanfarna áratugi hefur nádst gódur árangur við endurheimt og uppbyggingu gródurs og sjálfbærra skóga á Norðurlöndum og mikilvægt er að peirri vinnu verði haldið áfram.

Styrkja parf vitund um pá verðmætasköpun sem getur falist í nýtingu úrgangsefna, svo sem til moltugerðar og framleiðslu á mjöli og áburði. Með bættri nýtingu hráefna ásamt flokkun og nýtingu úrgangs má koma í veg fyrir myndun hans og draga úr neikvæðum umhverfisáhrifum.

Á undanförnum árum hefur Norræna ráðherranefndin unnið markvisst à pví að efla norræna umhverfismerkið Svaninn. Ísland hefur beitt sér fyrir 
framgangi Svansins heima fyrir og hefur pað meðal annars birst í fjölgun svansmerktra fyrirtækja. Íslendingar hafa verið leiðandi í undirbúningi og haft umsjón með framkvæmd peirrar stefnu sem gildir fyrir Svansmerkið til ársloka 2014. Á formennskuárinu verður lögð áhersla á að hefja undirbúning fyrir framtídarstefnumótun Svansins eftir 2014.

Hafið er uppspretta lífsgæða fyrir íbúa Norðurlanda. Miklar breytingar hafa ordiða ú umhverfi sjávar og stóran hluta af mengun hafsins má rekja til

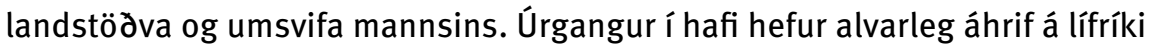
sjávar og heilsu fólks. Norræn og alpjódleg samvinna er forsenda árangurs til að takast á við mengun og súrnun sjávar og til að tryggja líffræðilega fjölbreytni i hafinu. Beita parf vistkerfanálgun við nýtingu audlinda hafsins og efla skipulag hafsvæða. Próa parf nýjar aðferðir og verkfæri til að tryggja skilvirka nýtingu og vernda hafsvæði og fiskistofna. í pví skyni er árídandi að auka pekkingu á ofaudgun, súrnun, loftslagsbreytingum og uppsöfnuðum áhrifum hættulegra efna á hafið. Unnið verður að pví að auka pekkingu á hættulegum eiginleikum efna í vörum, útbreiðslu peirra í umhverfinu og uppsprettum losunar í peim tilgangi að lágmarka skaðleg áhrif slíkra efna á heilsu fólks og umhverfi. Norrænt samstarf hefur pegar skilað sér í betra aðgengi að upplýsingum um efni og áhrif peirra. Mikilvægt er að stofnanir á sviði umhverfis- og neytendamála og samtök atvinnuvega á Norðurlöndum taki höndum saman um að styrkja upplýsingamiðlun og auka samstarf um eftirlit.

Íslendingar munu beita sér fyrir áframhaldandi samvinnu Norðurlanda á sviði loftslagsmála. Hvatt verður til að Norðurlönd styðji viðræður um gerð nýs hnattræns loftslagssamnings árið 2015 og leiti leiða til að brúa bilið milli iðnríkja og próunarlanda, meðal annars í gegnum samstarf norræna

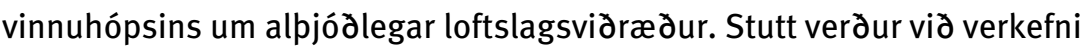
par sem Norðurlönd standa framarlega og geta miðlað af pekkingu sinni og reynslu, meðal annars um bindingu kolefnis í gróðri, jarðvegi og jarðlögum og ekki síst á sviði endurnýjanlegrar orku, svo sem vatnsorku, jarðhita, lífeldsneytis og vindorku. Orkurannsóknir skipta miklu pegar tekist er á við ný úrlausnarefni á sviði orkumála, í pví sambandi hefur stofnun um Norrænar orkurannsóknir gegnt lykilhlutverki. Par hafa Norðurlönd meðal annars haft áhrif á stefnumörkun og úrlausnir við innleiðingu Evrópugerða.

Orku- og umhverfismál eru nátengd og pví ber ad líta á audlindanýtingu og áhrif orkunotkunar á umhverfi á heildstæðan hátt. Samspil orku- og loftslagsmála, próun endurnýjanlegrar orku, orkunýtni og sampætting norræns raforkumarkadar eru áherslumál i norrænu samstarfi. 
Eitt stærsta viðfangsefnið er að skipta út jarðefnaeldsneyti fyrir umhverfisvænna eldsneyti. Á formennskuári Îslands verður unnið að orkuskiptum i samgöngum og leiða leitað til að leysa jarðefnaeldsneyti af hólmi en sérstaklega verður horft til orkunotkunar fiskiskipa. Áfram verður byggt á áherslum hnattvæðingarverkefna á sviði orkumála.

\section{VERKEF N I}

- Unnið verður að greiningu á viðnámsprótti vistkerfa og settar fram tillögur um hvernig uppbygging vistkerfa getur dregið úr áhrifum náttúruvár og loftslagsbreytinga á innviði samfélaga.

- Efnt verður til rádstefnu um framtíð samstarfs Norðurlanda um Svansmerkid.

- Unnið verður að próun sjálfbærniviðmiða um sjálfbæra nýtingu náttúruauðlinda.

- Haldin verður ráðstefna um breytingar á útbreiðslu fiskistofna í ljósi loftslagsbreytinga.

- Efnt verður til rádstefnu um rusl í hafi par sem áhersla verður lögðá hvernig má draga úr og fyrirbyggja pad í framtídinni.

- Ísland mun beita sér fyrir úttekt á niðurstöðum stefnumótunar um norræna skógarsamstarfið á grundvelli Selfoss-yfirlýsingar sem sampykkt var á rádstefnu skógarmálarádherranna árið 2009 og efna til umræðu um framtíðarstefnumörkun fyrir norræna skógarsamstarfið.

- Ísland mun taka virkan pátt i verkefnum á vegum Samstarfsnefndar um norrænar skógræktarrannsóknir.

- Unnið verður að orkumálum í samræmi við nýja samstarfsáætlun Norðurlanda i orkumálum sem tekur gildi árið 2014.

- Unnið verður að gæðastýringu orkukerfa. Í pví sambandi er áhersla lögd á að finna orkugjafa sem henta best til nýtingar hverju sinni. 



\section{Markmið:}

- Ad draga úr neikvæðum umhverfisáhrifum og tryggja sjálfbæra nýtingu auðlinda á öllum sviðum samfélagsins.

- Ad draga úr sóun og hámarka nýtingu og ábata af lífrænum afurdum.

- Ad efla nýsköpun, grænt atvinnulíf og byggðapróun.

- Að koma i veg fyrir myndun úrgangs og auka endurnýtingu.

Lífhagkerfið er mikilvæg stoð i hagkerfum allra Norðurlanda og er ein af meginstoðum græns hagvaxtar og sjálfbærni. Lífhagkerfið byggist á hagkerfi par sem nýting lífrænna afurða, úrgangsefna og annarra afurða sem til falla við vinnslu eru hámörkuð með pað fyrir augum að takmarka sóun úr virðiskeðjunni og draga úr umhverfisálagi, með hagsmuni og möguleika núlifandi og komandi kynslóda til að njóta pess sem náttúran gefur af sér að leiðarljósi. Stefnt verður að pví að auka sjálfbærni og ábata af nýtingu lífrænna audlinda, svo sem sjávarafla, beitilanda, skóga og landbúnaðarafurda.

Lífrænar auðlindir eru undirstaða velferðar á Norðurlöndum og hafa mikla pýðingu fyrir hagkerfi og atvinnulíf. Tryggja parf skilvirka nýtingu sem tekur mið af hagsmunum samfélags og umhverfis og stuðlar að hagvexti og uppbyggingu samkeppnishæfs atvinnulífs og samfélags án pess að pad hafi óafturkræfar afleiðingar. Afurðir verða nýttar til fullnustu, einnig verður lögd áhersla á að koma í veg fyrir myndun úrgangs og auka endurnýtingu aukaafurða sem til falla og draga par með úr umhverfisálagi og örva nýsköpun og grænt atvinnulíf.

Nýjar aðferðir og lausnir við nýtingu og framleiðslu bjóda upp á ýmsa möguleika, meðal annars til próunar og nýsköpunar. Pannig getur uppbygging lífhagkerfis styrkt atvinnulíf og rennt styrkari stoðum undir próun í peim byggðum sem helst eru hádar nýtingu lífrænna auðlinda. Lögð verður áhersla á að efla norrænt samstarf um nýjungar í menntun, rannsóknum, próun og nýsköpun í nánu samstarfi við atvinnulíf og menntastofnanir. Í pessu skyni verður unnið að fjölbreyttum verkefnum um próun menntunar og kennsluaðferða, vörupróunar og nýsköpunar í anda lífhagkerfisins. 


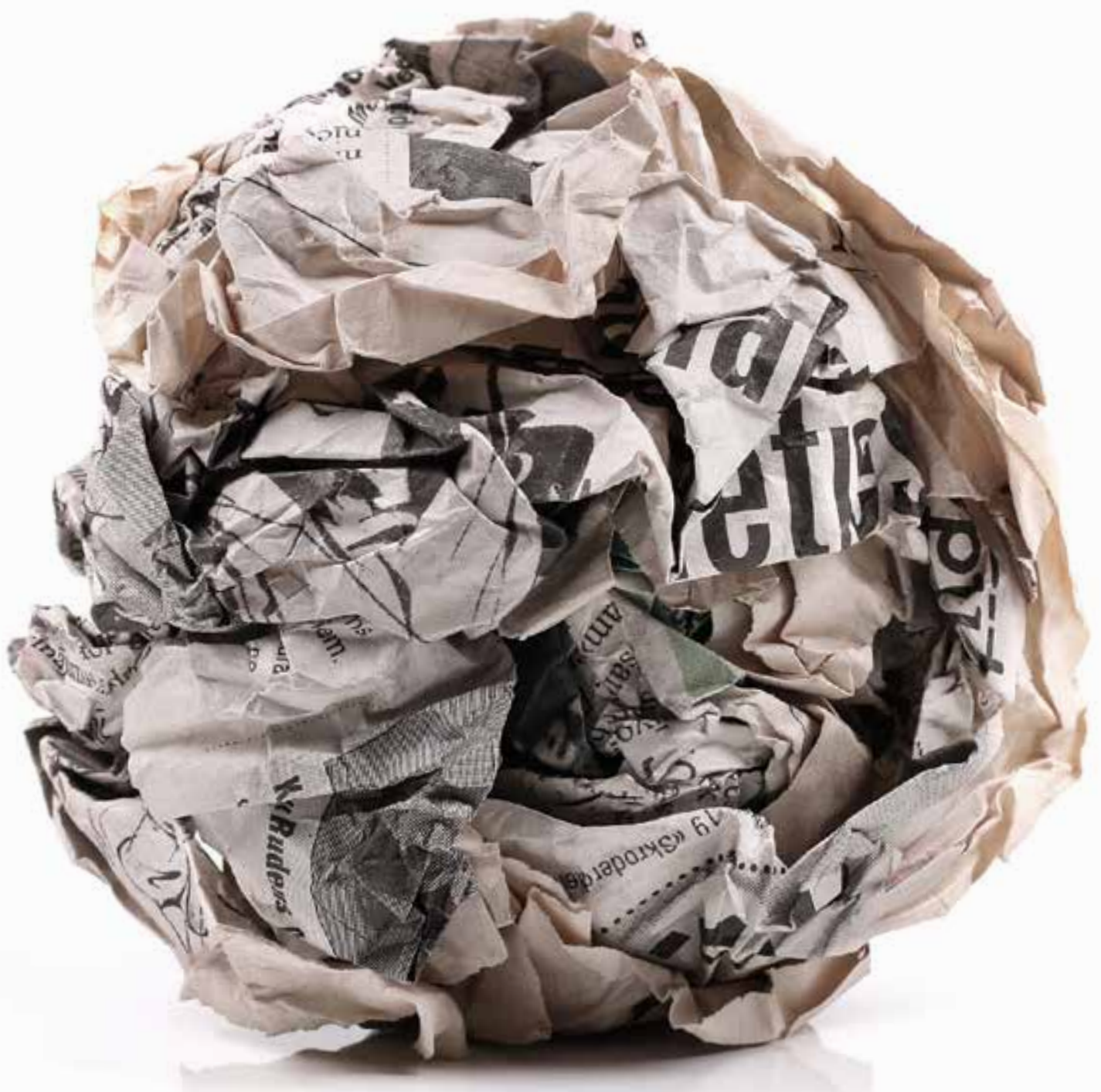




\section{Tækifæri til sóknar}

Próun sjálfbærra lausna um nýtingu lífrænna audlinda og hráefna og ad koma i veg fyrir myndun úrgangs og auka endurnýtingu verður í fyrirrúmi á formennskuárinu. Lífrænar auðlindir eru í mörgum tilvikum undirstada sjálfbærrar atvinnu- og byggdapróunar. Áherslur lífhagkerfisins opna tækifæri til umhverfisvænnar framleiðslu og nýsköpunar úr ólíkum lífrænum hráefnum og geta aukið verðmætasköpun í framleiðslu og tryggt sjálfbæra neyslu og nýtingu audlinda. Nýsköpun í norrænu atvinnulífi og skapandi greinum gegna mikilvægu hlutverki í grænni samfélagspróun. Mikilvægi pessara pátta er áréttað í samstarfsáætlun í nýsköpunar- og atvinnumálum sem tekur gildi á formennskuárinu.

Í starfandi fyrirtækjum og í hefðbundnum atvinnugreinum er að finna fjölmörg tækifæri til nýsköpunar. Nánar parf að skoða hlutverk stjórnvalda pegar kemur að pví að efla nýsköpun á Norðurlöndum. Aukin tækifæri til nýsköpunar gera fyrirtækjum kleift aə leggja fram nýjar lausnir og efla samkeppnisstöðu sína gagnvart erlendum aðilum.

Á formennskuárinu verður athygli beint að̃ norrænum haf- og strandsvæðum og landbúnaðar- og skógræktarsvæðum sem eru auðug af

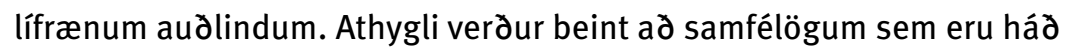
nýtingu pessara auðlinda sér til viðurværis. Stefnt er að pví að greina nánar tækifæri og áskoranir sem pessi svæði standa frammi fyrir, með áherslu á betri nýtingu auðlinda. Áhersla verður lögð á vörupróunarverkefni,

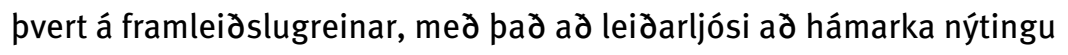
lífrænna afurða. Verkefnið verður unnið með virkri pátttöku atvinnulífs, rannsóknarstofnana, menntakerfis, stjórnsýslu og annarra hagsmunaadila.

Á Norðurlöndum er matvælaframleiðsla í háum gæðaflokki og kjöraðstæður fyrir hendi. Sjálfbær próun í landbúnaði og framleiðslugreinum verður æ mikilvægari, einkum og sér í lagi með hliðsjón af vaxandi fólksfjölda í heiminum. Norðurlönd geta lagt sitt lód á vogarskálarnar til að stuðla að auknu fæðuöryggi á heimsvísu. Höfuðmáli skiptir að efla rannsóknir, próun og nýsköpun pegar unnið er að sjálfbærum lausnum í framleiðslugreinum.

Rekjanleiki matvæla og virkt gæðaeftirlit eru veigamiklir pættir í matvælaöryggi. Fjöldi lítilla og meðalstórra fyrirtækja framleiða úr hráefnum úr nærumhverfi sínu og geta fyrir vikið aukið rekjanleika matvæla. Á Norðurlöndum er vaxandi áhugi meðal almennings á afurðum staðbundinnar 
matvælaframleiðslu. Pað veitir smærri framleiðendum tækifæri til að byggja upp traust medal neytenda og auka ávinning sinn. Með pví að hlúa að smáframleiðslu matvæla má allt í senn auka matvælaöryggi, verðmætasköpun og efla dreifðar byggðir par sem framleiðslan fer fram.

Áfram verður unnið að sjálfbærri svæðisbundinni velmegun, grænum vexti og eflingu sjálfbærrar próunar á heimskautasvæðum i samræmi við samstarfsáætlun í byggdamálum. Pá eru málefni strjálbýlla samfélaga og samstarfið á Vestur-Norðurlöndum Íslendingum hugleikin á formennskuári. Mörg strjálbýl samfélög hafa búið við langvarandi fólksfækkun prátt fyrir að ríkulegar audlindir sé að finna í næsta nágrenni. Pessar auðlindir hafa byggt

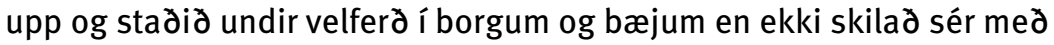
samsvarandi hætti til strjálbýlla samfélaga. Leitað verður leiða til að efla pau með nýsköpun, bættri nýtingu náttúruauðlinda og auknu samstarfi við rannsóknarstofnanir og háskóla. Sérstaklega verður horft til norðurslóda og hvaða áhrif aðgerðir í loftlagsmálum hafa á byggðir og lífsafkomu fólks á svæðinu. Pegar hefur verið hafin vinna við verkefnið Arctic Bioeconomy par sem sjónum er sérstaklega beint að viðfangsefnum á norðurslódum. 


\section{VERKEF N I}

- Áfram verður unnið að betri orkulausnum fyrir strjálbýl svæði enda er í mörgum tilfellum um að ræða svæði sem hafa takmarkaðan aðgang að sterkum orkudreifikerfum.

- Íslendingar munu styðja starf Norrænu rannsóknastofnunarinnar í skipulags- og byggdamálum (Nordregio) og Norræna Atlantshafssamstarfsins (NORA) enda gegna bádar stofnanirnar mikilvægu hlutverki í byggðapróun.

- Unnið verður að leiðum til að efla rannsóknir, próun og nýsköpun í matvælaframleidslu og landbúnaði.

- Leitað verður leiða til að taka á vanda strjálbýlla samfélaga sem búa við langvarandi fólksfækkun prátt fyrir að ríkulegar auðlindir séu i nánasta nágrenni. Í pví skyni verður lögð áhersla á að efla pessi samfélög með nýsköpun, bættri nýtingu náttúruauðlinda og auknu samstarfi við rannsóknarstofnanir og háskóla.

- Unnið verður að pví að kortleggja pau tækifæri sem felast i Norræna lífhagkerfinu og að skilgreina tækifæri til aukinnar verðmætasköpunar.

- Unnið verður að próunarverkefnum sem byggjast á bættri nýtingu lífauðlinda og aukinni verðmætasköpun.

- Haldnar verða ráðstefnur um fjölbreytt viðfangsefni tengd Norræna lifhagkerfinu.

- Samstarf Norðurlanda í málefnum sem tengjast sviðum lífhagkerfisins verður aukið.

- Stutt verður við próun verkefnis um samstarf opinberra aðila og einkaaðila um plöntukynbætur. Vinna við verkefnið hófst 2011. Íslendingar munu leggja sitt af mörkum til að styrkja pað og efla tækifærin sem í pví felast með hliðsjón af áherslum lífhagkerfisins. 


\section{Pekking á nýjum tímum}

Styrkur norræns atvinnulífs og pekkingarsamfélags á rætur í frjórri hugsun, kröftugri nýsköpun, öflugum rannsóknum og menntun sem eru atvinnulífi, byggðapróun og grænum hagvexti til framdráttar. Mikilvægt er að nýta pennan styrk til að skapa ný tækifæri fyrir norræn samfélög og gera peim kleift að takast á við úrlausnarefni dagsins.

Norðurlönd eru meðal peirra svæða í heiminum par sem nýsköpun og próun eru í miklum blóma og pví ber að viðhalda. Tækniframfarir og vaxandi samkeppni kalla á stöðuga endurskoðun á háskóla- og vísindastarfi. Efling rannsókna og háskóla stuðlar að nýsköpun og framförum og er forsenda árangurs. I háskóla- og rannsóknamálum hafa Norðurlönd stefnt að aukinni skilvirkni og verkaskiptingu milli stofnana. Huga parf enn betur að áherslum, sampættingu og samstarfi Norðurlanda með áherslu á tengingu ólíkra fagsviða, tækni, lista og vísinda svo styrkur peirra og sérpekking nýtist sem best. Margvísleg hæfni og pekking svo sem heilbrigdi og velferð, lýðræði og mannréttindi, jafnrétti, sjálfbærni, sköpun og læsi ásamt kunnáttu í stærðfræði, vísindum og tækni stuðlar að framförum í samfélaginu. Efla parf pessa pætti í pví skyni à byggja upp menntakerfi sem kemur til móts við kröfur og parfir nútímasamfélags og vinnumarkaðar.

Áherslur Íslands á sviði menntamála og vísinda byggja medal annars á áætlunum Norrænu rádherranefndarinnar um grænan vöxt og sjálfbæra norræna velferð. Bádar leggja ríka áherslu á hlutverk menntunar og rannsókna og mikilvægi peirra í stefnumótun. Samstarf pvert á stofnanir, fræðasvið og landamæri með hagnýtingu, pekkingarmyndun, nýsköpun, velferð og grænan vöxt að leiðarljósi skilar sér til Norðurlanda og eykur framlag peirra á alpjódlegum vettvangi.

Skapa parf tækifæri fyrir ungt fólk til að hasla sér völl í vísindum og nýsköpun með fjölbreyttum leiðum. Áfram verður unnið að próun verkefnisins um norrænt meistaranám og áherslum norrænna háskóla á gæði með samstarf, verkaskiptingu og sampjöppun að leiðarljósi. Hugað verður að bættri nýtingu upplýsingatækni til að miðla pekkingu og próa háskólanám óhád búsetu.

Aukin hnattvæðing með hröðum breytingum í upplýsingatækni og fjölbreyttur bakgrunnur nemenda í skólum kalla á aðlögun og frampróun í 
menntun, jafnt á inntaki skólastarfs og aðferðum. Gæði menntunar og virkni skólakerfisins byggist á hæfri fagstétt kennara. Pjódfélög sem vilja hasla sér völl í pekkingarhagkerfi nýrrar aldar purfa að huga vel að stefnumótun um störf og menntun kennara.

Uppbygging lífhagkerfisins undirstrikar mikilvægi samstarfs um nýjungar í menntun og próun og nýsköpun pvert á fagsvið. Í takt við petta verður unnið að próunarverkefnum á sviði mennta- og menningarmála sem kennd eru við hugmyndafræði Biophilia par sem leitast er við að sampætta menntun, vísindi og tækni með tónvísindasmiðjum og vísindamiðlun. í verkefninu er lögð áhersla á að tengja saman tækni, vísindi og sköpun pvert á skólastig, fræðasvið, stofnanir og atvinnulíf með nýjum hætti. Biophilia brýtur upp hið hefðbundna kennsluform og hvetur til víðtækrar pátttöku pvert á aldurshópa, námsgreinar og fagsvið par sem sköpun er notud sem menntunar- og rannsóknaraðferð. Hugmyndir og aðferðir Biophilia bjóda upp á sameiginlegan vettvang og grundvöll samstarfs, samráds og skoðanaskipta milli fólks á öllum aldri, listamanna sem vísindamanna, nemenda sem kennara. Pverfaglegt samstarf af pessu tagi stuðlar að próun kennsluhátta í takt við breytta tíma, proskar einstaklinginn og stuðlar að sjálfbæru samfélagi. 


\section{VERKEFN I}

- Unnið verður áfram að innleiðingu nýrra skipulags- og starfshátta á sviði rádherranefndar í menntamálum og vísindum (MR-U), í samræmi við fyrirliggjandi ákvarðanir sem byggja á skýrslu vinnuhóps frá í maí 2012.

- Skipulagt verður samstarfsnet innan byggðarlaga á Norðurlöndum par sem tengd verða saman mismunandi skólastig, stofnanir og atvinnulíf með áherslu á að auka nýsköpun, sjálfbærni, vísindi, sköpun og tækni í öllu skólastarfi.

- Unnið verður að samstarfsverkefni um norræna pekkingarlest. Með henni munu fulltrúar háskóla- og rannsóknastofnana ferðast um og efna til vísindaviðburða með pað fyrir augum að efla áhuga ungs fólks á rannsóknum og háskólanámi. Vinna við verkefnið mun fara fram í tengslum við núverandi viðfangsefni, t.d. net um pekkingarpríhyrning.

- Próað verður norrænt verkefni um bætta nýtingu pekkingar og svædisbundinna fjárframlaga í págu nýsköpunar. Markmiðið er að auka samstarf og sampættingu rannsókna og próunarstarfsemi, efla samstarf við háskóla og styðja við nýsköpun sem byggir á svæðisbundinni sérstöðu og tækifærum. Sérstaklega verður hugað að framlagi skapandi greina, lista, hugvísinda og félagsvísinda.

- Efnt verður til rádstefnu um starfspróun kennara og skólastjórnenda. Par verður menntun kennara á Norðurlöndum rædd og kastljósinu beint að möguleikum norrænu kennarastéttarinnar til að próa námsaðstæður og kennsluaðferði í takt við breytingar á tækni, samfélagi og menningu á 21. öldinni.

- Rádstefnan Norrænar brýr til ævimenntunar verður haldin í samstarfi við norræna samstarfsnetið um nám fullorðinna (NVL). Fjallað verður um próun nýrra aðferða í fullorðinsfræðslu og pann lærdóm sem draga má af stefnumótunarvinnu um málefnið.

- Îsland vill fylgja eftir áherslum Svípjódar um tengingu starfsmenntunar og vinnustadanáms. 


\section{Skapandi Norðurlönd}

Sameiginleg saga og menning Norðurlanda er ein af grunnstoðum norræns samstarfs og eykur samkennd og skilning milli landanna. Gildi norrænnar samvinnu endurspeglast í sameiginlegum hefðum og menningararfi, skyldleika tungumála og ekki síst í öflugri menntun og pekkingarpróun.

Norrænu menningarmálaráðherrarnir hafa sampykkt stefnu sem markar ramma samstarfsins og áherslur Norðurlanda á sviði menningarmála árin 2013-2020. Áætlunin byggist á fimm meginstoðum sem eru: sjálfbær Norðurlönd, skapandi Norðurlönd, pvermenningarleg Norðurlönd, ung Norðurlönd og stafræn Norðurlönd. Markmið áætlunarinnar er að styrkja og efla menningu Norðurlanda og stuðla að pátttöku sem flestra í menningarlífi. Virkt menningarlíf og aðgangur að menningu getur haft

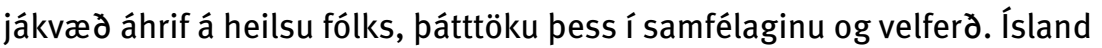
mun á formennskuárinu fylgja eftir áherslum Svía á pessu sviði og skoda nánar hvaða aðgerðir hafi reynst árangursríkar og hvernig má fylgja peim árangri eftir. Íslendingar munu á formennskuárinu styðja við menntun og rannsóknir sem snúa að sameiginlegri menningu og tungumálum. Auk pess verður sérstök áhersla lögðá að sampætta sköpun, menntun og vísindi með verkefninu Biophilia (sjá nánar á bls. 24).

Norræn samvinna byggist á pvermenningarlegu samstarfi ólíkra hópa, landa og aldurshópa par sem áherslur allra rúmast. Sérstaða samvinnunnar er sú að hún styrkir söguleg og menningarleg tengsl milli landanna. Pessum tengslum er viðhaldið i samstarfi fjölda áhugamannafélaga og með pátttöku almennings. Starf grasrótarsamtaka á menningar- og listasviðinu er mikilvægt fyrir norrænu samfélögin. Pessi samtök standa fyrir fjölbreyttum samstarfsverkefnum á norrænum vettvangi og vinna býðingarmikið starf í págu norrænnar menningar. Mikilvægt er að gera bessu samstarfi hátt undir höfði og efla pad.

Á formennskuárinu verður sjónum beint að hlutverki tónlistar og hönnunar. Sérstök athygli verður vakin á pessum greinum og peim komið á framfæri á breiðum vettvangi, til dæmis með pátttöku í tískutengdum viðburðum og Norræna spilunarlistanum (sjá nánar á bls. 30).

Stafræn tækni felur í sér fjölmörg tækifæri fyrir Norðurlönd, meðal annars til að styrkja sameiginlega upplifun sem tengist menningu og tungumálum. Notkun stafrænnar miðlunar er ákjósanleg leið til að tryggja 
aðgengi að norrænum listum og menningu og efla pekkingu og áhuga medal almennings. Auk pess er stafræn tækni stór páttur í pví að koma sameiginlegum menningararfi á framfæri og stuðla pannig að aukinni samkennd Norðurlanda. Lögð verður áhersla á að nýta stafræna tækni i

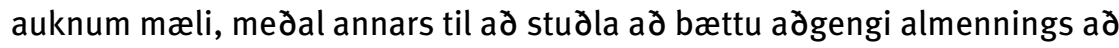
heimildum og gögnum sem geymd eru á pjódskjalasöfnum Norðurlanda.

Málefni barna og ungmenna eru eitt af forgangsmálum í norrænu samstarfi og endurspeglast pad í stefnumótun margra málaflokka. Yfirlýst markmið Norrænu ráðherranefndarinnar er að Norðurlönd eigi að vera besti staður í heimi fyrir börn og ungmenni. Pátttaka í menningarlífi og lýdræðislegu starfi er undirstaða lífsgæða og jafnréttis. Árið 2013 voru barna- og

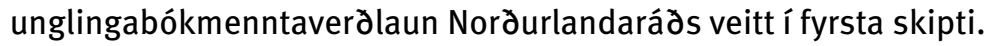

Með verðlaununum undirstrikar Norðurlandarád mikilvægi barna- og unglingabókmennta i menningarlífi Norðurlanda. Á formennskuárinu er rádgert að fylgja pessu átaki eftir og halda vidamikla hátíd á Íslandi um barna- og unglingabókmenntir. Stefnt er að bví ad halda slíka hátíd árlega.

Norðurlönd vinna saman að eflingu skapandi greina á ýmsum vettvangi, meðal annars innan KreaNord og með pátttöku í próun menningarsamstarfs innan Norðlægu víddarinnar. Pverfagleg samvinna á vettvangi KreaNord hefur stuðlað að auknu samstarfi milli atvinnulífs og menningartengdrar starfsemi og styrkt hvort tveggja í sessi.

Samstarfsáætlun í atvinnu- og nýsköpunarmálum fyrir árin 2014-2017 leggur áherslu á hlutverk menningartengdra greina og sköpunar fyrir hagvöxt. Pverfagleg samvinna á sviðum tengdum menningar- og atvinnumálum er nauðsynleg til að efla skapandi greinar.

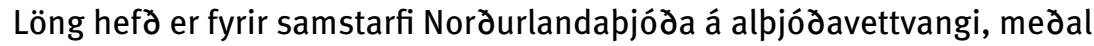
annars innan Menningarmálastofnunar Sameinuðu pjódanna (UNESCO). Einnig starfa UNESCO-nefndirnar á Norðurlöndum náið saman og funda reglulega. Löndin vinna saman ad málefnum heimsminjasamnings UNESCO, til dæmis á vettvangi norrænu heimsminjastofnunarinnar í Osló (NWHF) og Norræns tengslanets heimsminjastada. Ísland vill gera pessu samstarfi hátt undir höfði og beina sjónum að heimsminjasamningum og fleiri verkefnum tengdum UNESCO. Unnið hefur verið að verkefnum sem snúa að hlutverki menntunar til eflingar sjálfbærri próun, meðal annars i tengslum við loftslagsbreytingar. Slík verkefni hafa verið unnin í samræmi við áratug UNESCO um menntun til sjálfbærrar próunar sem lýkur árið 2014. Kannaðir verða möguleikar á frekara samstarfi um svipuð verkefni. 


\section{VER KEF N I}

- Norræni tískutvíæringurinn verður haldinn í Frankfurt 2014. Áherslan verður á listir og hönnun frá Færeyjum, Grænlandi og Íslandi. Norræna húsið í Reykjavík, í samvinnu við Norðurlandahúsið í Færeyjum og Norrænu stofnunina á Grænlandi, stendur að baki viðburðinum.

- Haldin verður rádstefna um mikilvægi frjálsra félagasamtaka og miðlun kunnáttu og reynslu frá eldri kynslóðum til peirra yngri. Leitað verður eftir samstarfi við Norræna félagið við skipulag ráðstefnunnar.

- Unnið verður að pví að setja á fót norræna vefgátt ríkisskjalasafna.

- Unnið verður að sampættingu menntunar, sköpunar og vísinda með verkefninu Biophilia undir formerkjum verkefnisins um Norræna liffhagkerfid.

- Ísland mun beita sér fyrir virkri pátttöku ungs fólks og félagasamtaka peirra í Biophiliu í samstarfi við norrænu barna- og ungmennanefndina.

- Barna- og unglingabókmenntaverðlaunum Norðurlandaráds verður fylgt eftir með norrænni barna- og unglingabókmenntahátíd á Íslandi.

- Norræna ljósið 2014, lista- og menningarhátíd fyrir ungmenni, verður haldin á formennskuárinu. Norræni menningarsjódurinn styrkir hátídina og hefur útnefnt hana sem Menningarviðburð Norðurlanda 2014.

- I I tilefni nýrrar pýdingar Íslendingasagnanna á dönsku, norsku og sænsku, sem út kemur árið 2014, verður gert átak íað kynna pann menningararf sem birtist í peim.

- Gerð verður úttekt á tengslum menningar og heilsu.

- Íslendingar munu hafa forystu um albjódlega radtilnefningu víkingaminja á heimsminjaskrá UNESCO.

- Haldið verður málping um UNESCO-samninga par sem fjallað verður um hvernig Norðurlönd geti haft samstarf innbyrðis um innleiðingu alpjódasamninga á menningarsviðinu. 
- Haldin verður rádstefna um óápreifanlegar menningarminjar í tengslum við sáttmála UNESCO um menningarerfðir í samvinnu við Norrænu pjódtónlistarsamtökin.

- Litið verður yfir áratug UNESCO um menntun til sjálfbærrar próunar og árangur af pví starfi dreginn saman.

- Unnið verður að pví að efla samstarf milli atvinnulífs og skapandi atvinnugreina. 


\section{Markmið:}

- Að efla Norðurlönd sem menningarsvæði og styrkja norræna samheldni.

- $\quad$ Ad audvelda adgengi ad norrænni tónlist og styrkja norrænan tónlistarmarkad.

- Ad koma norrænni tónlist á framfæri innan og utan Norðurlanda og auka útflutningsmöguleika.

Norræni spilunarlistinn er próunarverkefni á vegum norræna útflutningsverkefnisins NOMEX, sem er rekið af tónlistarútflutningsskrifstofum Norðurlanda. Spilunarlistinn sameinar notkun stafrænnar tækni og midlun norrænnar tónlistar á einfaldan hátt. Spilunarlistinn hefur pad að markmiði að koma norrænni tónlist á framfæri meðal íbúa Norðurlanda en einnig ad vekja athygli á norrænni tónlist, hljómsveitum og listamönnum innan sem utan Norðurlanda og greiða pannig fyrir auknum útflutningi tónlistar. Á heimasídu verkefnisins, www.nordicplaylist.com, og í gegnum tónlistarveitur á netinu verður à finna áhugaverðustu lögin frá öllum Norðurlöndum á einum spilunarlista sem verður uppfærður reglulega, ásamt fréttum af pví sem vinsælast er í hverju landi fyrir sig. Pannig getur almenningur fylgst með tónlistarsenu Norðurlanda og á auðveldan hátt nálgast pad sem ber hæst í norrænni tónlist á hverjum tíma. Framsetning

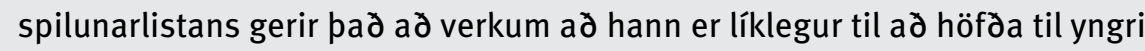
kynslóda en er aðgengilegur öllum, óhád aldri og búsetu. Med pví ad nýta nýjustu tækni má kveikja áhuga á tónlist Nordurlanda, menningu peirra og tungumálum og styrkja stoðir Norðurlanda sem lifandi menningarsvæðis.

Með Norræna spilunarlistanum má efla norræna menningu og skapandi greinar. Samhlida auknum áhuga og fjölgun hlustenda má styrkja norrænan tónlistarmarkad, fjölga atvinnutækifærum peirra sem starfa í tónlist og öðrum tengdum greinum sem getur skilad sér til norrænu samfélaganna med margvíslegum hætti. Norræn tónlist nýtur aukinnar athygli utan Nordurlanda og pví mikilvægt ad nýta pau tækifæri sem í pví felast. Skapandi greinar og efling peirra eru mikilvægir staksteinar á leið til græns hagkerfis enda eru pær í grunninn sjálfbærar.

www.nordicplaylist.com 

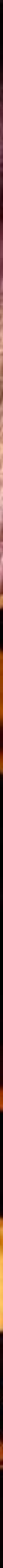


\section{Velferð og pátttaka}

Norrænu velferðarkerfin standa frammi fyrir nýjum viðfangsefnum sem krefjast lausna og fjölpættrar samvinnu; alpjódlegar fjármálakreppur, lýðfrædilegar breytingar og atvinnuleysi eru dæmi um slíkt. Meðal viðfangsefna er að sporna gegn einangrun og tryggja pátttöku borgaranna, jöfnuð, félagslegt öryggi og góda heilbrigðis- og félagspjónustu. Yfirlýsing forsætisrádherra Norðurlanda um sjálfbæra norræna velferð fyrir árin 2013-2015 er leiðandi fyrir samvinnu á sviði velferðarmála á formennskuári Íslands.

Margt getur haft áhrif á heilsu og vellídan fólks. Ákvarðanir og stefnumótun í stofnunum eða á alpjóðlegum vettvangi geta haft áhrif á heilsu, bæði til góds og ills. Mikilvægt er að ákvarðanataka hafi pað að markmiði að auka lífsgæði einstaklinga og fjölskyldna.

Árangur félags- og heilbrigðispjónustu byggist á rannsóknum par sem er leitast við að finna og próa nýjar lausnir. Brýnt er að stjórnvöld, almenningur og hagsmunaaðilar hafi gott aðgengi að gögnum og geti fylgst með próun og breytingum í samfélaginu. Með formennskuverkefninu Norræna velferðarvaktin (sjá nánar á bls. 38) munu Íslendingar leggja sitt af mörkum til að skapa og tryggja aðgengi að slíkum upplýsingum. Einnig skiptir stöðugt umbótastarf og gæðapróun miklu máli pegar kemur að pví að bæta pjónustu og úrræði sem í boði eru. Leggja parf mat á gæði og árangur aðgerða og pjónustu með reglulegu millibili og efla samrád og samvinnu norrænna sérfræðinga. Málefni mænuskaddaðra verða til umfjöllunar á formennskuárinu og skoðað verður hvernig má efla samstarf Norðurlanda um bætta meðferð við mænuskaða.

Íslendingar munu leggja áherslu á mikilvægi heilbrigðs lífsstíls fyrir heilsu og vellí̉an. Sjónum verður beint að neikvæðum afleiðingum slæmra lifnaðarhátta, til dæmis ofpyngdar og neyslu áfengis, tóbaks og annarra vímugjafa. Ísland mun beita sér fyrir auknu samstarfi Norðurlanda á sviði lyfjamála en nauðsynlegt er að bregðast við og koma í veg fyrir of- og misnotkun ákveðinna lyfja sem er vaxandi vandamál alls staðar á Norðurlöndum og kostnaðarsamt fyrir samfélögin.

Íslendingar vilja stuðla að aukinni samvinnu Norðurlanda á sviði velferðartækni. Pannig geta Norðurlönd í sameiningu lagt fram hugmyndir að lausnum sem geta viðhaldið eða aukið gæði og öryggi i félags- og 


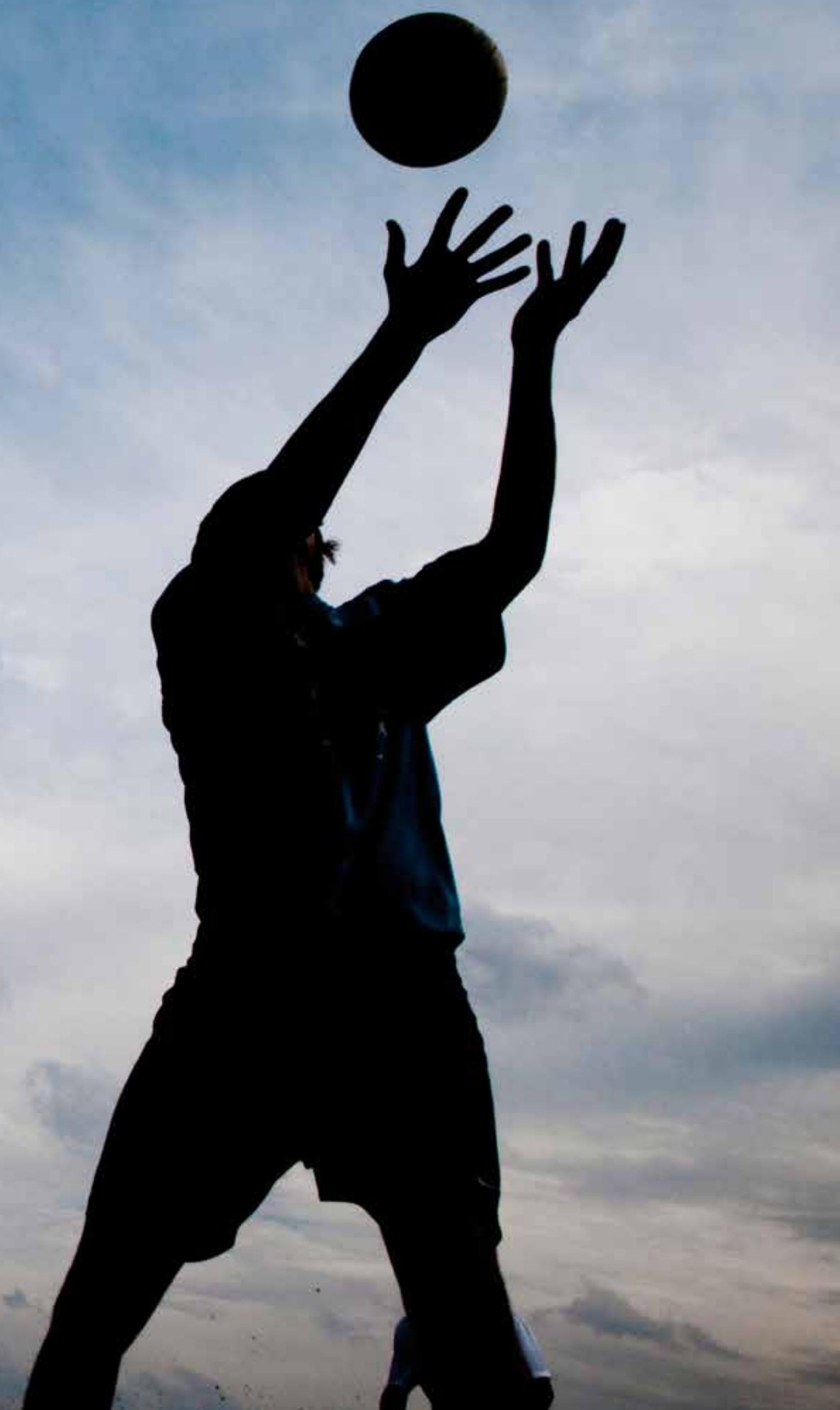


heilbrigðispjónustu. Pá hafa Norðurlönd ákveðið að auka samvinnu í klínískum rannsóknum. í pví sambandi er mikilvægt að koma á umræðu um hvernig megi einfalda og samræma ýmsa pætti varðandi gerð rannsóknaráætlana og umsóknir til sida- og persónuverndarnefnda.

\section{Á formennskuári verður sérstaklega hugað að málefnum barna og} fjölskyldna. Vellíðan barna og gott samspil milli samfélags og fjölskyldu ýtir undir pátttöku og leggur grunn að heilbrigðri og farsælli samfélagspróun.

Pátttaka í atvinnulífi er forsenda vellídanar og jafnframt einn af hornsteinum norrænu velferðarsamfélaganna. Efnahagskreppur undanfarinna ára hafa dregið úr möguleikum fólks með skerta færni á pátttöku í atvinnulífi. Mikilvægt er að sporna gegn atvinnuleysi ungs fólks og peirra sem minna mega sín. Langtímaatvinnuleysi og samspil mennta- og vinnumarkaðsmála verður í brennidepli á formennskuári Îslands.

Stjórnvöld á Norðurlöndum hafa varpað fram peirri spurningu hvort skortur á öflugri tengingu milli hins hefðbundna skólakerfis og atvinnulífsins leiði til pess að ungt fólk fái ekki reynslu og innsýn í almenn störf í fyrirtækjum sem er mikilvægur hluti af proskaferli hvers einstaklings. Munu Íslendingar fylgja eftir frumkvædi Svía um eflingu vinnustadanáms og tengsla pess við atvinnulíf og skóla. Sjónum verður beint að próun skólakerfisins og

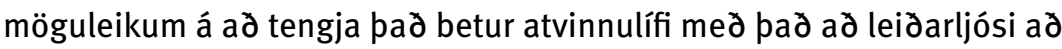
ungt fólk hljóti starfspjálfun í fyrirtækjum sem hluta af námi. Leitað verður leiða til pess að efla möguleika atvinnuleitenda á starfspjálfun pannig að starfspjálfun innan fyrirtækja geti orðið hluti af starfsleitaráætlunum. Lögð er áhersla á að yfirvöld menntamála og vinnumála sameinist i umræðu um pessi mál. Brýnt er að próun í menntamálum haldist î hendur vid próun samfélags og atvinnulífs pannig að hvert styðji annað og stuðli að vídtækri pátttöku.

Íslendingar vilja stuðla að bví ad sem flestir hafi möguleika á að vera á vinnumarkadi á eigin forsendum. Störf purfa að vera fjölbreytt og koma til móts við parfir einstaklinga pannig að hver og einn geti fundið verkefni og vinnu við hæfi. Vinnuumhverfi parf að vera öruggt og heilsusamlegt og í samræmi við líkamlega og andlega færni starfsmanna í gegnum æviferilinn en um leið göfgandi og hvetjandi. Petta kallar á sveigjanlegan vinnumarkað sem getur aðlagast mismunandi getu einstaklinga. Einnig parf með virkri

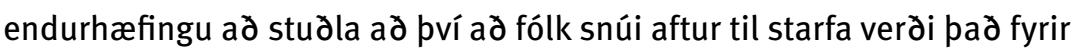
heilsutjóni vegna sjúkdóma og slysa. Hvetjandi vinnuumhverfi og virkt stoðkerfi stuðla að betri heilsu og gera fólki kleift að vera á vinnumarkaði sem lengst. 
Norðurlönd hafa staðið sig einna best í að tryggja jafnrétti kynjanna og hafa

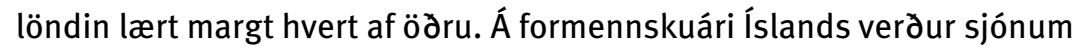
beint að stöðu og jafnrétti á vinnumarkaði, kynskiptum vinnumarkaði og leiðum til að samræma fjölskyldulíf og atvinnu. Sérstök áhersla verður á verkefni og umræður um launajafnrétti. Einnig verður pátttaka karla i jafnréttismálum, aðgerðir gegn kynbundnu ofbeldi og samstarf um jafnréttismál á Vestur-Norðurlöndum í brennidepli á formennskuárinu. Ísland hefur ætí̉ lagt áherslu á málefni Vestur-Norðurlanda og strjálbýlla samfélaga í norrænu samstarfi. í pví samstarfi verður lögd áhersla á samhengi jafnréttis kynjanna, fjölskyldulífs og jafnréttis á vinnumarkadi. Umræður um málefni norðurslóða hafa að miklu leyti snúist um auðlindanýtingu og afleiðingar umhverfisbreytinga fyrir náttúru og mannlíf á norður-

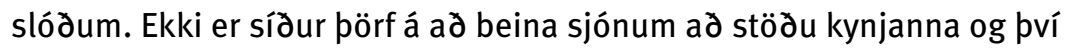
hvaða áhrif pær umhverfis- og samfélagsbreytingar sem hafa átt sér stad og eru fram undan muni hafa á kynin hvort um sig.

Öll löndin undirbúa innleiðingu á samningi Evrópurádsins um forvarnir og baráttu gegn ofbeldi gegn konum og heimilisofbeldi. Undanfarið hefur athygli ekki síst beinst að áhrifum ofbeldis og kynferðisofbeldis á börn. Unnið er að norrænu verkefni um samræmt áhættumat varðandi heimilisofbeldi. Mikilvægt er að miðla pekkingu um árangursríkar aðgerðir og hvar frekari vinnu er pörf.

Pegar tekist er á við ný viðfangsefni á sviði velferðar purfa margir aðilar að koma ad málum. Ísland mun á formennskuárinu leggja áherslu á samrád, samvinnu og sampættingu úrræða pvert á stofnanir og stjórnsýslustig. 


\section{VERKEF N I}

- Farið verður yfir stöдu norrænna samvinnuverkefna, stofnana og nefnda sem starfa á sviði félags- og heilbrigðismála og gildi peirra fyrir Norðurlönd.

- Unnið verður að pví að próa skráningu í velferdarbjónustu.

- Efnt verður til rádstefnu um fjölskyldur, velferð barna og fjölskyldustefnur á Norðurlöndum.

- Efnt verður til umræðu um mikilvægi almannaheillasamtaka fyrir norræna velferð.

- Efnt verður til aukins samráds milli Norðurlanda um forvarnir og nýjar leiðir til að bregðast við afleiðingum slæmra lifnaðarhátta.

- Norrænir og alpjódlegir sérfræðingar á sviði mænuskada munu koma saman og meta árangur meðferðar við mænuskaða.

- Samstarf Norðurlanda í lyfjamálum verður eflt.

- Farið verður yfir reynslu Norðurlanda af sampættingu heimahjúkrunar og félagslegrar heimapjónustu.

- Haldið verður áfram með samvinnu innan Nordic Trial Alliance.

- Efnt verður til rádstefnu um vinnumarkad, vinnuvernd í gegnum æviferilinn og starfsendurhæfingu með aðkomu sérfræðinga í starfsendurhæfingu, vinnumarkaðs- og vinnuverndarmálum.

- Haldin verður rádstefna um starfspjálfun sem hluta af hefðbundnu námi í samvinnu rádherranefnda vinnu- og menntamála.

- Í tilefni 60 ára afmælis norræns samstarfs í vinnumarkaðsmálum verður haldin rádstefna um vinnumál i samvinnu við aðila vinnumarkaðarins á Norðurlöndum.

- Kvennaráðstefnan Nordisk Forum verður haldin í Malmö. Ráðstefnan er á vegum frjálsra félagasamtaka á Norðurlöndum. 
- Rannsóknarverkefninu Hlutastörf, kyn og efnahagslegur ávinningur lýkur á haustmánuðum 2014 með rádstefnu.

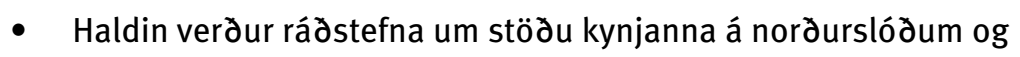
aðkomu peirra að stefnumótun og ákvarðanatöku í málefnum er varða samfélags- og hagpróun.

- Haldin verður rádstefna í Færeyjum um markmið og leiðir í jafnréttismálum.

- Haldin verður rádstefna um karlarannsóknir og jafnrétti.

- Haldin verður ráðstefna um aðgerðir til að draga úr kynbundnu ofbeldi par sem fjallað verður um farsælar aðgerðir á Norðurlöndum.

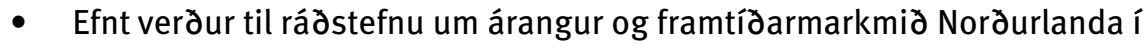
jafnréttismálum í tilefni 40 ára afmælis jafnréttissamstarfs Nordurlanda.

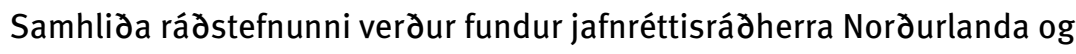
Eistlands, Lettlands og Litháens. 


\section{Markmið:}

- Ad rannsaka áhrif fjármálaprenginga og tengdra afleiðinga á norrænu velferðarkerfin.

- Að stuðla að upplýstri stefnumótun í velferðarmálum.

- Ad draga úr áhrifum heilsutengdra vandamála á velferdo og auka sjálfbærni norrænu velferðarkerfanna.

Norræna velferðarvaktin mun rannsaka afleiðingar fjármálaprenginga á norrænu velferdarkerfin og áhrif peirra á heilsufar, velferð og atvinnupátttöku.

Norðurlönd hafa öll á einhverjum tímapunkti gengið í gegnum og purft að takast á við fjármálakreppur og afleiðingar peirra. Pessi reynsla

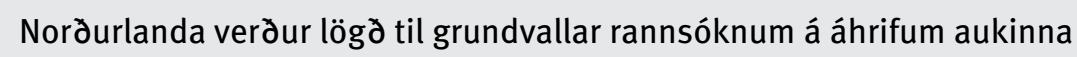
efnahagslegra byrda, langvarandi álags og atvinnuleysis á andlega og líkamlega heilsu, velferd og lífsskilyrði íbúa og ákveðinna hópa fólks. Pá verða viðbrögð Norðurlanda við fjármálakreppum skoðuð, metið verður hvaða aðgerðir hafi skilad árangri og hvar megi gera betur til að fyrirbyggja neikvæðar afleiðingar af fjármálakreppum á samfélög og velferð.

Norræna velferðarvaktin miðar að bví að styrkja stoðir og efla sjálfbærni norrænu velferðarkerfanna með samvinnu, rannsóknum og gagnkvæmri miðlun peirrar reynslu og pekkingar sem til verður. Markmiðið er jafnframt að próa lausnir og samhæfa aðgerðir til að mæta komandi áskorunum og að próa velferðarvísa sem geta nýst við stefnumótun. Pannig má byggja upp öflugan rannsóknakjarna par sem hægt er að sækja upplýsingar og hagnýta pekkingu sem getur nýst Norðurlöndum við stefnumótun og ákvarðanatöku í velferðarmálum eða ef svipaðar aðstæður koma upp í framtíðinni. Með pví geta löndin brugðist við og reynt að draga úr neikvæðum áhrifum á velferð. Norðurlönd geta lært hvert af öəru, nýtt reynslu og pekkingu hvert annars til gagns og í sameiningu mætt komandi áskorunum, staðið vörð um og stuðlað að sjálfbærri norrænni velferð til langframa. 


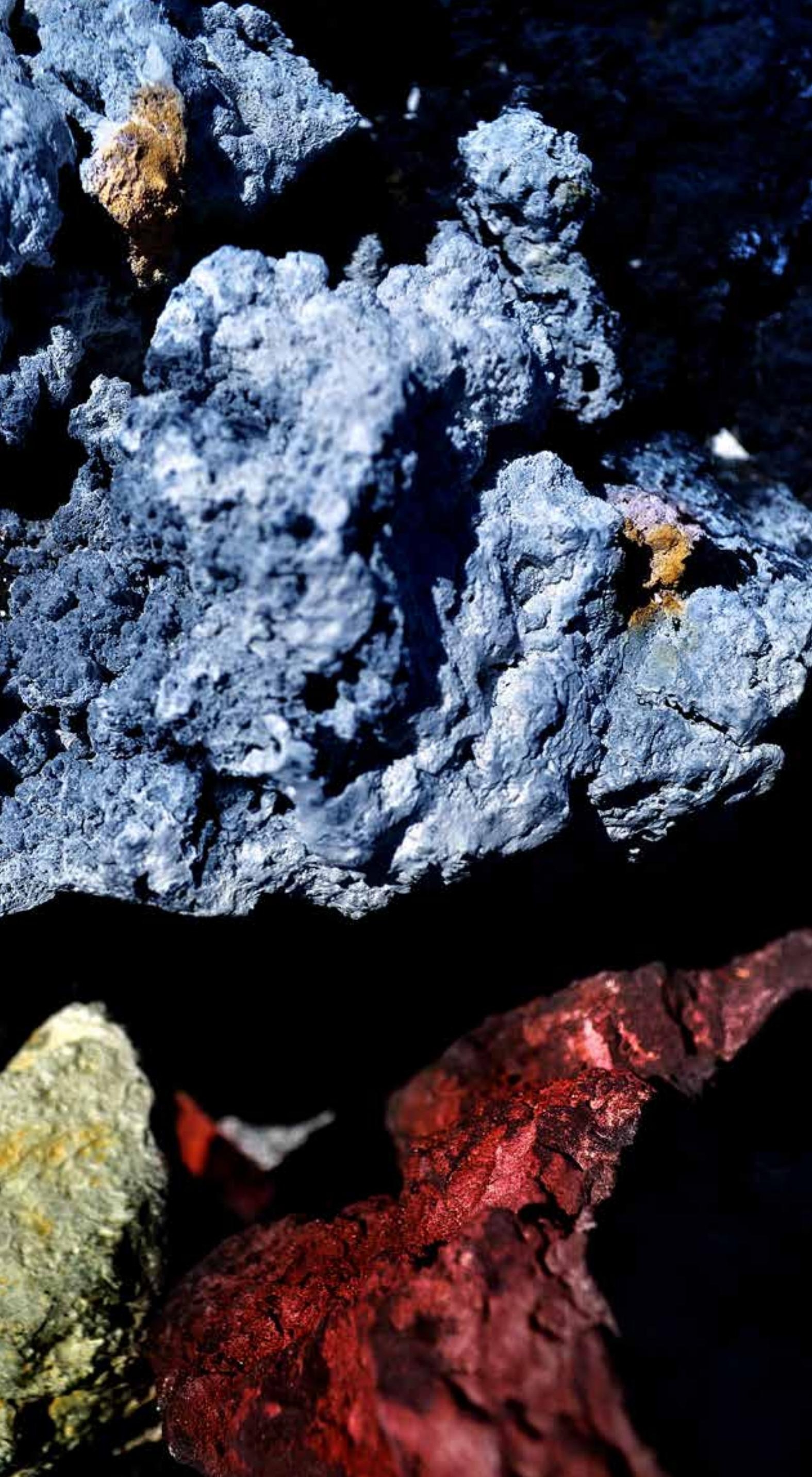


norden

Norræna rádherranefndin

Ved Stranden 18

DK-1061 København K

www.norden.org

Frekari upplýsingar um
formennsku Íslands í Norrænu
rádherranefndinni má finna á
www.norden2014.is og
www.nordic2014.com.
Utanríkisráduneytid
Norðurlandaskrifstofa
Raudarárstígur 25
IS-105 Reykjavík
Ísland
Sími: +354 5459900

ANP 2013:768

ISBN 978-92-893-2620-9 